Short-term levosimendan treatment protects rat testes against oxidative stress

M.B. Yuksel, S. Kavak, I. Gecit, H. Basel, H.A. Gümrükçüoğlu, H. Demir and İ. Meral

The Brazilian Journal of Medical and Biological Research is partially financed by

\section{QR CNPq} Conselth Nacional de Descon
Cientifico e Tecrologico
Ministério da Ciência e Tecnologia

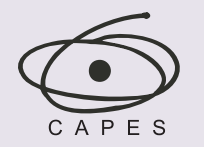

Ministério da Educação

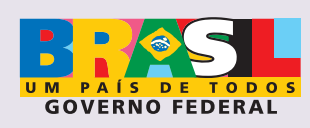

\title{
Institutional Sponsors
}

soiplo
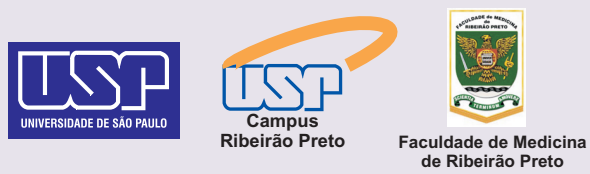

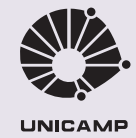

UNICAMP

\section{Ф SHIMADZU}

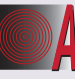

AfFl

Associaçando

Fundo
de Incentivo
à Pesquisa à Pesquisa

Explore High - Performance MS Orbitrap Technology

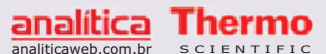




\title{
Short-term levosimendan treatment protects rat testes against oxidative stress
}

\author{
M.B. Yuksel ${ }^{1}$, S. Kavak², I. Gecit ${ }^{3}$, H. Basel ${ }^{4}$, H.A. Gümrükçüoğlư ${ }^{5}$, \\ H. Demir 6 and İ. Meral ${ }^{7}$ \\ ${ }^{1}$ Urology Clinic, The State Hospital of Mus, Mus, Turkey \\ ${ }^{2}$ Department of Biophysics, Faculty of Medicine, Yüzüncü Yil University, Van, Turkey \\ ${ }^{3}$ Department of Urology, Faculty of Medicine, Yüzüncü Yil University, Van, Turkey \\ ${ }^{4}$ Department of Cardiovascular Surgery, Bezmi Alem Foundation University Hospital, Istanbul, Turkey \\ ${ }^{5}$ Cardiology Department, Faculty of Medicine, Yüzüncü Yil University, Van, Turkey \\ ${ }^{6}$ Division of Biochemistry, Department of Chemistry, Faculty of Science, Yüzüncü Yil University, Van, Turkey \\ ${ }^{7}$ Department of Physiology, Faculty of Medicine, Yüzüncü Yil University, Van, Turkey
}

\begin{abstract}
The objective of this study was to evaluate the effect of short-term levosimendan exposure on oxidant/antioxidant status and trace element levels in the testes of rats under physiological conditions. Twenty male Wistar albino rats were randomly divided into two groups of 10 animals each. Group 1 was not exposed to levosimendan and served as control. Levosimendan (12 $\mu \mathrm{g} /$ $\mathrm{kg}$ ) diluted in $10 \mathrm{~mL} 0.9 \% \mathrm{NaCl}$ was administered intraperitoneally to group 2. Animals of both groups were sacrificed after 3 days and their testes were harvested for the determination of changes in tissue oxidant/antioxidant status and trace element levels. Tissue malondialdehyde (MDA) was significantly lower in the levosimendan group $(P<0.001)$ than in the untreated control group and superoxide dismutase and glutathione peroxidase (GSH-Px) levels were significantly higher in the levosimendan group $(P<0.001)$. Carbonic anhydrase, catalase and GSH levels were not significantly different from controls. Mg and $\mathrm{Zn}$ levels of testes were significantly higher $(\mathrm{P}<0.001)$ and $\mathrm{Co}, \mathrm{Pb}, \mathrm{Cd}, \mathrm{Mn}$, and Cu were significantly lower $(\mathrm{P}<0.001)$ in group 2 compared to group 1. Fe levels were similar for the two groups $(P=0.94)$. These results suggest that 3 -day exposure to levosimendan induced a significant decrease in tissue MDA level, which is a lipid peroxidation product and an indicator of oxidative stress, and a significant increase in the activity of an important number of the enzymes that protect against oxidative stress in rat testes.
\end{abstract}

Key words: Levosimendan; Oxidative stress; Reactive oxygen species; Rat testes; SOD; GSH-Px; MDA

\section{Introduction}

Oxidative stress triggers a cascade that leads to the production of reactive oxygen species (ROS), accumulation of lipid peroxidation products such as malondialdehyde (MDA), massive secretion of systemic inflammatory mediators that can result in the development of systemic inflammatory response syndromes, impaired cell function, and multiple organ dysfunctions (1-4), while the antioxidant enzymes superoxide dismutase (SOD) and glutathione peroxidase (GSH-Px) play important roles in cell defense against oxidative stress. Antioxidants in cells, such as SOD, catalase (CAT), glutathione (GSH), and $\mathrm{GSH}-\mathrm{Px}$ protect the organism against the damages of oxidative stress (5).

Under physiological conditions, the testes are vulnerable to oxidative stress. The testes have a poor vascularization, which means that oxygen tension in this tissue is low (6). Spermatogenesis is an extremely active replicate process. The high rates of cell division inherent in this process imply correspondingly high rates of mitochondrial oxygen consumption by the germinal epithelium. The competition for this element within the testes is extremely intense. Despite the low oxygen tensions that characterize the testicular microenvironment, this tissue remains vulnerable to oxidative stress due to the abundance of highly unsaturated fatty acids and the presence of potential ROS-producing systems. Since both spermatogenesis and Leydig cell steroidogenesis are vulnerable to oxidative stress, the low oxygen tension may be an important component of the

Correspondence: I. Gecit, Department of Urology, Faculty of Medicine, Yüzüncü Yıl University, 65100 Van, Turkey.

Fax: +90-4322167519. E-mail: ilhan_gecit@hotmail.com

Received December 23, 2011. Accepted May 4, 2012. Available online May 18, 2012. Published August 3, 2012. 
mechanisms by which the testes protect themselves from free radical-mediated damage (7-9). Furthermore, the testes have an elaborate array of antioxidant enzymes and free radical scavengers to ensure that the twin spermatogenic and steroidogenic functions of this organ are not impacted by oxidative stress.

Levosimendan is a recently synthesized positive inotropic drug that improves myocardial contraction by the calcium sensitization of the contractile protein troponin $\mathrm{C}$ without increasing calcium concentration in myocardial cells, and also has a vasodilating effect by opening adenosine triphosphate-sensitive potassium channels (10). It was reported that a single dose of levosimendan seems to have anti-inflammatory and anti-apoptotic properties, reducing circulating proinflammatory cytokines and soluble apoptosis mediators (11). We thought that this agent, with its anti-inflammatory and anti-apoptotic properties, might affect the related mechanisms of oxidative stress in the testicular tissues that are vulnerable to oxidative stress under physiological conditions.

The aim of this experimental study was to evaluate the possible influences of short-term levosimendan exposure on oxidant/antioxidant status and trace element levels in the rat testes under physiological conditions.

\section{Material and Methods}

\section{Treatment of animals}

Twenty male Wistar albino rats, approximately 6 months of age, with an average body weight of 250-300 g were obtained from the Animal Laboratory of Yüzüncü Yil University, Van, Turkey. Rats were housed in cages with 5 rats per cage. A 12-h light/dark cycle was maintained and the rats were fed ad libitum. The study was approved by the Ethics Committee of he study was approved by the Ethics Committee of Yüzüncü Yil University.

The animals were randomly divided into two groups, each consisting of 10 rats. The animals in group 1 were not treated with the drug and served as control. In group 2, levosimendan (12 $\mu \mathrm{g} \cdot \mathrm{kg}^{-1} \cdot \mathrm{day}^{-1}$, diluted in $10 \mathrm{~mL} 0.9 \%$ $\mathrm{NaCl}$, ip, for 3 days) was injected intraperitoneally. After 3 days, animals in both groups were sacrificed and their testes were harvested for the evaluation of tissue oxidant/ antioxidant status and trace element levels after short-term levosimendan exposure.

\section{Biochemical analysis}

Measurement of MDA level. A 50-mg tissue specimen was homogenized in $0.15 \mathrm{M} \mathrm{KCl}$. After centrifugation of the homogenate at $1600 \mathrm{~g}$, MDA levels in tissue homogenate supernatant were determined by thiobarbituric acid (TBA) reaction according to Kavak et al. (12,13). The principle of this method is based on measuring absorbance of the pink color produced by the interaction of TBA with MDA at $530 \mathrm{~nm}$. MDA levels are reported as $\mathrm{mg} / \mathrm{dL}$.
Measurements of SOD and GSH-Px enzyme activities. The tissues were homogenized in physiological saline (1 $\mathrm{g}$ in $5 \mathrm{~mL}$ ) using a homogenizer (B. Braun Melsungen AG 853202, Germany) and centrifuged at $4000 \mathrm{~g}$ for $20 \mathrm{~min}$ (Heraus Labofur 200, Germany). GSH-Px activity was determined by monitoring the changes in NADPH absorbance at $340 \mathrm{~nm}(14)$ and by measuring the decrease of $\mathrm{H}_{2} \mathrm{O}_{2}$ absorbance at $240 \mathrm{~nm}$ (15). SOD activity was measured by the method based on nitroblue tetrazolium (NBT) reduction rate. One unit of SOD activity is the amount of enzyme protein causing $50 \%$ inhibition of NBT reduction rate (16). SOD and GSH-Px activities are reported as $\mathrm{mIU} / \mathrm{mg}$ and $\mathrm{EU} / \mathrm{g} \mathrm{Hb}$, respectively.

Measurement of GSH level. GSH levels were measured by the technique of Sedlak and Lindsay (17) at $412 \mathrm{~nm}$. The samples were precipitated with 50\% TCA and centrifuged at $1000 \mathrm{~g}$ for $5 \mathrm{~min}$. The reaction mixture contained $0.5 \mathrm{~mL}$ supernatant, $2.0 \mathrm{~mL}$ Tris-EDTA buffer (0.2 M, pH 8.9) and $0.1 \mathrm{~mL} 10 \mathrm{mM} \mathrm{5,5}$ '-dithiobis-(2-nitrobenzoic acid; DTNB). The solution was kept at room temperature for $5 \mathrm{~min}$ and subsequently absorbance was read at $412 \mathrm{~nm}$. GSH levels are reported as $\mathrm{mIU} / \mathrm{mg}$.

Measurement of CAT enzyme activity. Erythrocyte CAT activity was measured by the method described by Aebi (18). Briefly, the supernatant $(0.1 \mathrm{~mL})$ was added to a quartz cuvette containing $2.95 \mathrm{~mL} 19 \mathrm{mM} \mathrm{H}_{2} \mathrm{O}_{2}$ prepared in potassium phosphate buffer $(50 \mathrm{mM}, \mathrm{pH} 7.0)$. The change in absorbance was monitored at $240 \mathrm{~nm}$ for 5 min using a Shimadzu spectrophotometer (UV-1201, Japan). CAT activity is reported as EU/g Hb.

Measurement of carbonic anhydrase (CA) activity. CA activity was assayed by hydration of $\mathrm{CO}_{2}$ measured by the method of Rickli and Wilbur-Anderson (19) using bromothymol blue as indicator. CA activity is reported as $\mathrm{EU} / \mathrm{g} \mathrm{Hb}$.

Measurements of mineral levels. Two milliliters of the mixture of $\mathrm{HNO}_{3} / \mathrm{H}_{2} \mathrm{O}_{2}$ (2:1) was added to $0.7 \mathrm{~g}$ of the tissue sample. The mixture was placed in a water bath at $70^{\circ} \mathrm{C}$ for $30 \mathrm{~min}$, stirred occasionally, and subsequently, $1.0 \mathrm{~mL}$ of the same acid mixture was added, and the suspension was transferred to a Teflon vessel for digestion in a microwave oven. The bomb was closed and radiation was applied for 3 $\mathrm{min}$ at $450 \mathrm{~W}$. After the addition of $0.5 \mathrm{~mL}$ of the same acid mixture, radiation was repeated for $3 \mathrm{~min}$. After cooling for 5 $\min , 2.0 \mathrm{~mL} 0.1 \mathrm{M} \mathrm{HNO}_{3}$ was added, and the solution was transferred to a Pyrex tube. After centrifugation, the clear solution was used for the determination of $\mathrm{Cu}, \mathrm{Zn}, \mathrm{Mg}, \mathrm{Mn}$, $\mathrm{Pb}, \mathrm{Cd}$, and $\mathrm{Fe}(20,21)$. Measurements were performed by atomic absorption spectrophotometry using a UNICAM-929 spectrophotometer (Unicam Ltd., UK). Trace element levels are reported in $\mu \mathrm{g} / \mathrm{dL}$.

\section{Statistical analysis}

Data are reported as means $\pm S D$. The parameters were compared between the two groups using the Mann-Whitney 
U-test. All statistical analyses were carried out using the SPSS ${ }^{\circledR}$ statistical software package (SPSS for Windows version 13.0, SPSS Inc., USA) and a $P$ value of $\leq 0.05$ was considered to be significant.

\section{Results}

All measurements were performed using appropriate analyses that demonstrated only the values of the parameters evaluated in the testicular tissues of rats. The tissue MDA level, which is as an indicator of oxidative stress, was $125.168 \pm 3.702 \mathrm{mg} / \mathrm{dL}$ in group 1 and $99.667 \pm 1.657 \mathrm{mg} /$ $\mathrm{dL}$ in group 2 being significantly lower in the levosimendan group $(P<0.001)$. The levels of protective enzyme such as SOD and GSH-Px, which play important roles in cell defense against oxidative stress (5), were $11.465 \pm 0.441$ $\mathrm{mIU} / \mathrm{mg}$ and $80.926 \pm 1.466 \mathrm{EU} / \mathrm{g} \mathrm{Hb}$ in group 1 , and 22.945 $\pm 4.405 \mathrm{mlU} / \mathrm{mg}$ and $111.108 \pm 5.470 \mathrm{EU} / \mathrm{g} \mathrm{Hb}$ in group 2, respectively, being significantly higher in group $2(P<0.001)$. Nevertheless, there was no significant difference in CA, CAT, or GSH levels between group $1(0.072$ $\pm 0.005 \mathrm{EU} / \mathrm{g} \mathrm{Hb}, 72.609 \pm 2.649 \mathrm{EU} / \mathrm{g}$ $\mathrm{Hb}, 76.418 \pm 1.807 \mathrm{mlU} / \mathrm{mg}$ ) and group $2(0.080 \pm 0.026 \mathrm{EU} / \mathrm{g} \mathrm{Hb}, 76.098 \pm$ $6.338 \mathrm{EU} / \mathrm{g} \mathrm{Hb}, 79.199 \pm 3.440 \mathrm{mIU} / \mathrm{mg}$, respectively). These data are presented in detail (minimum, maximum and mean \pm SD values) and compared in Table 1.

Trace element levels were also analyzed in the two groups. $\mathrm{Mg}$ and $\mathrm{Zn}$ were $15.82 \pm 0.73$ and $1.694 \pm 0.273 \mu \mathrm{g} / \mathrm{dL}$ in group $1,24.11 \pm 1.19$ and $3.98 \pm 0.432$ $\mu \mathrm{g} / \mathrm{dL}$ in group 2 , respectively, with their values being significantly higher in the levosimendan group $(P<0.001)$. Nevertheless, $\mathrm{Co}, \mathrm{Pb}, \mathrm{Cd}, \mathrm{Mn}$, and $\mathrm{Cu}$, with values of $0.6 \pm 0.04,0.16 \pm 0.01,0.08 \pm 0.002$, $0.03 \pm 0.008$, and $17.64 \pm 0.69 \mu \mathrm{g} / \mathrm{dL}$ in group 1 , and $0.44 \pm 0.02,0.05 \pm 0.006$, $0.04 \pm 0.004,0.01 \pm 0.003$, and $11.41 \pm$ $1.25 \mu \mathrm{g} / \mathrm{dL}$ in group 2 , respectively, were significantly lower in group $2(\mathrm{P}<0.001)$. Fe level was found to be $3.67 \pm 0.53 \mu \mathrm{g} / \mathrm{dL}$ in group 1 and $3.64 \pm 0.51 \mu \mathrm{g} / \mathrm{dL}$ in group 2 , with similar values for the two groups ( $P$ $=0.94)$. These data and their comparisons are presented in Table 2.

\section{Discussion}

The testes have an extremely active replication period and therefore imply correspondingly high rates of mitochondrial oxygen consumption by the germinal tive stress. epithelium. In addition, low oxygen tensions in this tissue and high requirement of oxygen within the testes cause an intense competition for this vital element (6). The testes contain antioxidant enzymes and free radical scavengers presumably to ensure that spermatogenic and steroidogenic functions are not impacted by oxidative stress (7-9). Peroxidative damage is currently regarded as the single most important cause of impaired testicular function underpinning the pathological consequences of a wide range of conditions from testicular torsion to diabetes and xenobiotic exposure (7-9). Thus, these antioxidant defense systems are of major importance (7-9).

The testes have developed antioxidant defense systems comprising both enzymatic and non-enzymatic constituents. Concerning the enzymatic constituents of this defense system, the induction of oxidative stress in the testes precipitates a response characterized by the nuclear factor KB (NFKB)-mediated induction of mRNA species for SOD,

Table 1. Effect of levosimendan administration on tissue levels of MDA, an indicator of oxidative stress, and the levels of enzymes that act in cell defense against oxida-

\begin{tabular}{lcc}
\hline Enzyme activity & Control group (group 1) & Levosimendan group (group 2) \\
\hline SOD $(\mathrm{mlU} / \mathrm{mg})$ & $11.4 \pm 0.44(10.6-11.8)$ & $22.9 \pm 4.4^{*}(19.06-30.8)$ \\
MDA $(\mathrm{mg} / \mathrm{dL})$ & $125.1 \pm 3.7(121.3-129.5)$ & $99.6 \pm 1.6^{*}(97.6-101.4)$ \\
GSH-Px $(\mathrm{EU} / \mathrm{g} \mathrm{Hb})$ & $80.9 \pm 1.4(80.01-83.8)$ & $111.1 \pm 5.4^{*}(104.3-115.7)$ \\
GSH $(\mathrm{mlU} / \mathrm{mg})$ & $76.4 \pm 1.8(74.1-78.3)$ & $79.1 \pm 3.4(76.02-85.6)$ \\
CA $(\mathrm{EU} / \mathrm{g} \mathrm{Hb})$ & $0.07 \pm 0.005(0.07-0.08)$ & $0.08 \pm 0.02(0.03-0.1)$ \\
CAT $(\mathrm{EU} / \mathrm{g} \mathrm{Hb})$ & $72.6 \pm 2.6(70.8-76.04)$ & $76.1 \pm 6.3(66.2-82.05)$ \\
\hline
\end{tabular}

Data are reported as means $\pm S D$ and with range in parentheses for $N=10 /$ group. Rats were treated with levosimendan $\left(12 \mu \mathrm{g} \cdot \mathrm{kg}^{-1} \cdot\right.$ day $\left.^{-1}, i p\right)$ for 3 days. SOD = superoxide dismutase; GSH-Px = glutathione peroxidase; $\mathrm{CA}=$ carbonic anhydrase; $\mathrm{CAT}=$ catalase $; \mathrm{GSH}=$ antioxidant glutathione; $\mathrm{MDA}=$ malondialdehyde. ${ }^{*} \mathrm{P}<0.001$ compared to control.

Table 2. Effect of levosimendan treatment on testicular tissue trace element levels.

\begin{tabular}{lcc}
\hline & Control group (group 1) & Levosimendan group (group 2) \\
\hline $\mathrm{Co}$ & $0.6 \pm 0.04(0.5-0.6)$ & $0.44 \pm 0.02^{*}(0.4-0.4)$ \\
$\mathrm{Pb}$ & $0.16 \pm 0.01(0.1-0.2)$ & $0.05 \pm 0.006^{*}(0.05-0.06)$ \\
$\mathrm{Cd}$ & $0.08 \pm 0.002(0.08-0.08)$ & $0.04 \pm 0.004^{*}(0.03-0.04)$ \\
$\mathrm{Mg}$ & $15.8 \pm 0.7(15.03-17.2)$ & $24.1 \pm 1.2^{*}(22.7-25.8)$ \\
$\mathrm{Mn}$ & $0.03 \pm 0.008(0.02-0.04)$ & $0.01 \pm 0.003^{*}(0.01-0.02)$ \\
$\mathrm{Fe}$ & $3.67 \pm 0.5(3.3-4.7)$ & $3.64 \pm 0.5(3.1-4.6)$ \\
$\mathrm{Cu}$ & $17.6 \pm 0.7(17.03-18.9)$ & $11.4 \pm 1.2^{*}(9.1-12.4)$ \\
$\mathrm{Zn}$ & $1.7 \pm 0.2(1.1-1.8)$ & $3.9 \pm 0.4^{*}(3.2-4.4)$ \\
\hline
\end{tabular}

Data are reported in $\mu \mathrm{g} / \mathrm{dL}$ as means $\pm \mathrm{SD}$ with range in parentheses for $\mathrm{N}=10$ / group. Rats were treated with levosimendan $\left(12 \mu \mathrm{g} \cdot \mathrm{kg}^{-1} \cdot \mathrm{day}^{-1}\right.$, ip) for 3 days. Co $=$ cobalt; $\mathrm{Cd}=$ cadmium; $\mathrm{Mg}=$ magnesium; $\mathrm{Mn}=$ manganese; $\mathrm{Zn}=$ zinc; $\mathrm{Co}=$ copper; $\mathrm{Fe}=$ iron; $\mathrm{Pb}=$ lead. ${ }^{*} \mathrm{P}<0.001$ compared to control. 
GSH-Px and glutathione-S-transferase (GSH-S-T) activities (22). SOD, a family of enzymes that catalyze the dismutation of two superoxide anions $\left(\mathrm{O}_{2}^{-} \cdot\right)$ to hydrogen peroxide $\left(\mathrm{H}_{2} \mathrm{O}_{2}\right)$ and molecular oxygen, reduce tissue concentrations of superoxide radicals in order to prevent the induction of oxidative damage to lipids, proteins and DNA $(23,24)$. The elimination of $\mathrm{H}_{2} \mathrm{O}_{2}$ is effected by catalase or glutathione peroxidase, with the latter predominating in the case of the testes $(25,26)$. CAT is mainly a heme-containing enzyme. The predominant subcellular localization of the enzyme is in peroxisomes, in which it catalyzes the dismutation of hydrogen peroxide to water and molecular oxygen $(24,27)$.

In the present study, we evaluated the effect of short-term exposure of levosimendan on oxidant/antioxidant status and trace element levels in testes of healthy rats. To our knowledge, this is the first study that evaluated the alterations in oxidant-antioxidant status and some trace element levels in the testes of a living organism after short-term levosimendan exposure. We have demonstrated that the tissue MDA level, which is a lipid peroxidation product and an indicator of oxidative stress, was significantly lower in the levosimendantreated group $(P<0.001)$. These data indicated that 3-day short-term levosimendan treatment presented a significant decrease in MDA levels in the testes of rats, thus appearing to indirectly protect the testicular tissues against oxidative stress by decreasing the lipid peroxidation product. However, an important part of the protective enzyme activities including SOD and GSH-Px, which play important roles in cell defense against oxidative stress (5), was significantly higher in group $2(P<0.001)$. These data could also be interpreted to mean that this agent improved the protective mechanisms against the damages of oxidative stress by increasing some enzymatic defense mechanisms in the testicular tissues of rats. Even though the functions of antioxidant trace elements is not well known, our study showed that, while $\mathrm{Mg}$ and $\mathrm{Zn}$ levels were significantly higher $(P<0.001)$, Co, $\mathrm{Pb}, \mathrm{Cd}, \mathrm{Mn}$, and $\mathrm{Cu}$ levels were significantly lower $(P<0.001)$ in group 2. Furthermore, Fe level was similar for the two groups $(P=$

\section{References}

1. Adams JG Jr, Dhar A, Shukla SD, Silver D. Effect of pentoxifylline on tissue injury and platelet-activating factor production during ischemia-reperfusion injury. $J$ Vasc Surg 1995; 21: 742-748.

2. Troyer-Caudle J. Reperfusion injury. J Vasc Nurs 1993; 11 : 76-79.

3. Sucu N, Unlu A, Tamer L, Aytacoglu B, Coskun B, Bilgin R, et al. Effects of trimetazidine on tissue damage in kidney after hindlimb ischemia-reperfusion. Pharmacol Res 2002; 46: 345-349.

4. Neary P, Redmond HP. Ischemia-reperfusion injury and the systemic inflammatory response syndrome. Ischemiareperfusion injury. London: Blackwell Science; 1999.

5. Özer AB, Kaman D. Effects of epigallocatechin 3-gallate
0.94). A number of studies suggested that $Z n$ deficiency can be the major cause of the increase in oxidative damage to tissues (28). Therefore, we may hypothesize that $\mathrm{Zn}$ might be an important factor for the response of the antioxidant system in germ cells. It has been suggested that Zn may be involved in several components of the oxidant defense including $\mathrm{Cu} / \mathrm{Zn} \mathrm{SOD}$, an essential component of the antioxidant system (29), and that the formation of spermatids is affected by Mg deficiency. It has also been reported that the increase of MDA (lipid peroxidation) in the testes depends on $\mathrm{Mg}$ deficiency (30).

Although the antioxidant defense systems protect the testes against oxidative damage in order to support its dual functions of steroidogenesis and sperm production, a wide spectrum of endogenous and exogenous factors are known to disturb these defenses and to generate a state of oxidative stress. These pathological factors that damage the testes and their twin functions with their own mechanisms containing oxidative stress include cryptorchidism (31,32), testicular torsion (33-36), varicocele (37), infection, and diabetes mellitus (38). However, some analyses have shown significant protection against oxidative stress by some agents such as garlic extract (33), caffeic acid phenethyl ester (36), N-acetyl cysteine (39), pentoxifylline (40), resveratrol (34), and L-carnitine (35).

In conclusion, the present study revealed that short-term levosimendan exposure induced a significant decrease in tissue levels of MDA, which is a lipid peroxidation product and an indicator of oxidative stress, and a significant increase in an important part of protective enzyme activities against oxidative stress including SOD and GSH-Px, which play important roles in cell defense against oxidative stress. These data were interpreted to indicate that short-term levosimendan exposure supported the protection of rat testes under physiological conditions against oxidative stress by preventing lipid peroxidation, and also overactivating and/ or increasing the protective antioxidant enzymes in the testes of rats. However, this requires more detailed and comprehensive studies. in rat cardiac tissue on oxidant and antioxidant system exposed to sevoflurane anesthesia. Fýrat Týp Dergisi 2007; 12: 93-96.

6. Free MJ, Schluntz GA, Jaffe RA. Respiratory gas tensions in tissues and fluids of the male rat reproductive tract. Biol Reprod 1976; 14: 481-488.

7. Peltola V, Mantyla E, Huhtaniemi I, Ahotupa M. Lipid peroxidation and antioxidant enzyme activities in the rat testis after cigarette smoke inhalation or administration of polychlorinated biphenyls or polychlorinated naphthalenes. J Androl 1994; 15: 353-361.

8. Quinn PG, Payne AH. Oxygen-mediated damage of microsomal cytochrome P-450 enzymes in cultured Leydig cells. Role in steroidogenic desensitization. J Biol Chem 
1984; 259: 4130-4135.

9. Chen H, Liu J, Luo L, Baig MU, Kim JM, Zirkin BR. Vitamin E, aging and Leydig cell steroidogenesis. Exp Gerontol 2005; 40: 728-736

10. Follath F, Cleland JG, Just H, Papp JG, Scholz H, Peuhkurinen $\mathrm{K}$, et al. Efficacy and safety of intravenous levosimendan compared with dobutamine in severe low-output heart failure (the LIDO study): a randomised double-blind trial. Lancet 2002; 360: 196-202.

11. Parissis JT, Adamopoulos S, Antoniades C, Kostakis G, Rigas A, Kyrzopoulos S, et al. Effects of levosimendan on circulating pro-inflammatory cytokines and soluble apoptosis mediators in patients with decompensated advanced heart failure. Am J Cardiol 2004; 93: 1309-1312.

12. Kavak S, Ayaz L, Emre M, Inal T, Tamer L, Gunay I. The effects of rosiglitazone on oxidative stress and lipid profile in left ventricular muscles of diabetic rats. Cell Biochem Funct 2008; 26: 478-485.

13. Kavak S, Ayaz L, Emre M. Effects of insulin on oxidative stress and free fatty acid level in left ventricular muscles of diabetic rats. Asian J Chem 2009; 21: 5677-5684.

14. Paglia DE, Valentine WN. Studies on the quantitative and qualitative characterization of erythrocyte glutathione peroxidase. J Lab Clin Med 1967; 70: 158-169.

15. Aebi $\mathrm{H}$. Catalase in vitro. In: Bergmayer HU (Editor), Methods of enzymatic analysis. New York: Academic Press Inc.; 1974. p 673-677.

16. Durak I, Canbolat O, Kavutcu M, Ozturk HS, Yurtarslani Z. Activities of total, cytoplasmic, and mitochondrial superoxide dismutase enzymes in sera and pleural fluids from patients with lung cancer. J Clin Lab Anal 1996; 10: 17-20.

17. Sedlak J, Lindsay RH. Estimation of total, protein-bound, and nonprotein sulfhydryl groups in tissue with Ellman's reagent. Anal Biochem 1968; 25: 192-205.

18. Aebi H. Catalase in vitro. Methods Enzymol 1984; 105: 121 126.

19. Rickli EE, Ghazanfar SA, Gibbons BH, Edsall JT. Carbonic anhydrases from human erythrocytes. Preparation and properties of two enzymes. J Biol Chem 1964; 239: 10651078.

20. Bush VJ, Moyer TP, Batts KP, Parisi JE. Essential and toxic element concentrations in fresh and formalin-fixed human autopsy tissues. Clin Chem 1995; 41: 284-294.

21. Yaman M, Akdeniz I. Sensitivity enhancement in flame atomic absorption spectrometry for determination of copper in human thyroid tissues. Anal Sci 2004; 20: 1363-1366.

22. Kaur P, Kaur G, Bansal MP. Tertiary-butyl hydroperoxide induced oxidative stress and male reproductive activity in mice: role of transcription factor NF-kappaB and testicular antioxidant enzymes. Reprod Toxicol 2006; 22: 479-484.

23. Kang YJ, Chen Y, Epstein PN. Suppression of doxorubicin cardiotoxicity by overexpression of catalase in the heart of transgenic mice. J Biol Chem 1996; 271: 12610-12616.

24. Nordberg J, Arner ES. Reactive oxygen species, antioxidants, and the mammalian thioredoxin system. Free Radic Biol Med 2001; 31: 1287-1312.
25. Zini A, Schlegel PN. Catalase mRNA expression in the male rat reproductive tract. J Androl 1996; 17: 473-480.

26. Peltola V, Huhtaniemi I, Ahotupa M. Antioxidant enzyme activity in the maturing rat testis. J Androl 1992; 13: 450-455.

27. Yazar E, Konyalioglu S, Col R, Osman Birdane Y, Levent $B$, Elmas M. Effects of vitamin $E$ and prednisolone on some oxidative stress markers in endotoxemic rabbits. Rev Méd Vét 2004; 155: 538-542.

28. Oteiza PL, Olin KL, Fraga CG, Keen CL. Oxidant defense systems in testes from zinc-deficient rats. Proc Soc Exp Biol Med 1996; 213: 85-91.

29. Celino FT, Yamaguchi S, Miura C, Ohta T, Tozawa Y, Iwai T, et al. Tolerance of spermatogonia to oxidative stress is due to high levels of $\mathrm{Zn}$ and $\mathrm{Cu} / \mathrm{Zn}$ superoxide dismutase. PLoS One 2011; 6: e16938.

30. Merker HJ, Gunther T, Hollriegl V, Vormann J, Schumann K. Lipid peroxidation and morphology of rat testis in magnesium deficiency. Andrologia 1996; 28: 43-51.

31. Ikeda M, Kodama H, Fukuda J, Shimizu Y, Murata M, Kumagai $\mathrm{J}$, et al. Role of radical oxygen species in rat testicular germ cell apoptosis induced by heat stress. Biol Reprod 1999; 61: 393-399.

32. Smith R, Kaune H, Parodi D, Madariaga M, Morales I, Rios $\mathrm{R}$, et al. [Extent of sperm DNA damage in spermatozoa from men examined for infertility. Relationship with oxidative stress]. Rev Med Chil 2007; 135: 279-286.

33. Unsal A, Eroglu M, Avci A, Cimentepe E, Guven C, Derya $\mathrm{BM}$, et al. Protective role of natural antioxidant supplementation on testicular tissue after testicular torsion and detorsion. Scand J Urol Nephrol 2006; 40: 17-22.

34. Uguralp S, Usta U, Mizrak B. Resveratrol may reduce apoptosis of rat testicular germ cells after experimental testicular torsion. Eur J Pediatr Surg 2005; 15: 333-336.

35. Dokmeci D, Inan M, Basaran UN, Yalcin O, Aydogdu N, Turan FN, et al. Protective effect of L-carnitine on testicular ischaemia-reperfusion injury in rats. Cell Biochem Funct 2007; 25: 611-618.

36. Atik E, Gorur S, Kiper AN. The effect of caffeic acid phenethyl ester (CAPE) on histopathological changes in testicular ischemia-reperfusion injury. Pharmacol Res 2006; 54: 293-297.

37. Agarwal A, Prabakaran S, Allamaneni SS. Relationship between oxidative stress, varicocele and infertility: a metaanalysis. Reprod Biomed Online 2006; 12: 630-633.

38. Agbaje IM, Rogers DA, McVicar CM, McClure N, Atkinson $A B$, Mallidis $C$, et al. Insulin dependent diabetes mellitus: implications for male reproductive function. Hum Reprod 2007; 22: 1871-1877.

39. Cay A, Alver A, Kucuk M, Isik O, Eminagaoglu MS, Karahan $\mathrm{SC}$, et al. The effects of $\mathrm{N}$-acetylcysteine on antioxidant enzyme activities in experimental testicular torsion. J Surg Res 2006; 131: 199-203.

40. Liu ZM, Zheng XM, Yang ZW, Li SW. [Protective effect of pentoxifylline on spermatogenesis following testicular torsion/detorsion in rats]. Zhonghua Nan Ke Xue 2006; 12: $323-5,329$ 